\title{
Analysis of Factors Affecting Student Learning Difficulties Toward Physiology Anatomy Lesson at SMK Negeri 3 Tangerang (Case Study Class X of Cosmetology at SMK 3 Tangerang)
}

\author{
Eti Herawati ${ }^{1,}$ Lilies Yulasti ${ }^{2,}$ Diah Ayu Hapsari Purnomo ${ }^{3}$ \\ ${ }^{1,2,3}$ Faculty of Engineering, State University of Jakarta
}

\begin{abstract}
This study aims to determine factors that cause learning difficulties to anatomy and physiology subjects lesson by class X student cosmetology Programs at SMK Negeri 3 Tangerang in Academic Year 2016/2017 with a survey method. The populations were 64 people from class X students and Data collection tool used is questionnaires. The trial questionnaires carried out by 25 class XI cosmetology respondents. Instrument analysis carried out on validity and reliability, with 40 statement items and reliability result $r 11=0.954$. The results of this study showed that the factors affecting students' difficulties mainly on internal factors that are motivational factors indicators with sub student $88 \%$ learning persistence factor and independent learning factor equal to $94 \%$. While external factors are indicators of teacher attention factor, with teachers sub-factor appreciation to students' difficulties by $84 \%$, and the factor of teachers' involvement in students activities is equal to $91 \%$. The hypothesis testing results were obtained through a regression equation where the results obtained $\mathrm{Y}=101,286+879 \mathrm{X}$, showing that any increase in the value of a teacher's attention every 101,286 can cause an 879 increase with learning difficulties showed the $6.1 \%$ test effect, coefficient determination while the remaining $93.9 \%$ is influenced by other factors.
\end{abstract}

Keywords: factors of learning difficulties, physiology anatomy

\section{INTRODUCTION}

Education has an important role in the intellectual life of the nation, the development of human life history has proven that the nation level improvement is greatly influenced by the level of education.

Learning is a basic process of the human life development. By learning, humans make individual qualitative changes so that their behaviour develops. All human life activities and achievements are nothing but the results of learning. Learning is not just an experience, but also a process, not a result. Therefore learning takes place actively and integratively by using various action forms to achieve a goal.

To realize the national education goals a special institution is needed to manage education in such a way, school is in this case. This means that the bad and good life of nation, where the ability of the nation in the future is determined by the school in providing educational services to the community. The role of schools as educational institutions has the role to create quality of human resources with educational programs that sourced from information in the community, which is then used as educational curriculum material and implemented by graduates as a provision for living according to the demands of society.

Vocational secondary schools as part of secondary education institutions aim to prepare graduates to have work skills after the education process is completed. More specifically the purpose of education in vocational schools is listed in the education minister's decree number 080 / U / 1993 regarding the curriculum.

Referring to the objectives stated in the education minister's decree number 080 / U / 1993, vocational secondary schools such as SMK Negeri 3 Tangerang are required to prepare their students to become professional graduates and able to fill the needs of the workforce.

SMK Negeri 3 Tangerang is one of the formal education institutions which consists of several vocational courses namely Culinary, Fashion, Cosmetology, Hospitality Accommodation, and Computer Network Engineering. The cosmetology of the SMK Negeri 3 Tangerang is divided into 2 namely skin Cosmetology and hair Cosmetology. In class $\mathrm{X}$ for majoring in cosmetology there is one subject of anatomy and physiology related to basic science to determine the structure and function of the human body.

Anatomy and physiology is one of the basic competencies in the subjects of vocational competency on cosmetology education training program for the first year in Vocational School. The basic competency of anatomy and physiology especially in the subject of skin and hair anatomy is one of the skills that must be managed fundamentally to continue the learning activities. Therefore the learning of skin and 
hair anatomy in the first year emphasizes the direct experience through the use and development of process skills and scientific attitudes so that students are able to identify the anatomy of physiology of the skin and hair then applied it in accordance with the rules and treatment procedures.

To achieve the goal, students need to have a good interest and ability towards anatomical physiology subjects that have implications with the tasks and responsibilities as a strategic to the teachers of anatomy physiology. They are required to help students get a good understanding of physiological anatomy subjects. This means the physiological anatomy learning process that carried out by the teacher should bring the potention of material understanding, attitudes and increase students' interest in anatomical physiology lessons.

In fact, students are often unable to achieve their learning goals as expected. Meanwhile each student has different abilities. There are students who can achieve it without difficulty, but many students also experience difficulties. This means the success or failure of achieving educational goals is very dependent on the learning experienced by students, both when he is in school and in the home environment or in his family environment.

Based on researchers observations at SMK 3 Tangerang, the authors found some students seemed to experience obstacles and difficulties in following anatomical physiology subjects. There are several factors that can be used as material for analysis including internal factors and external factors. The internal factors that can cause difficulties in following the teaching-learning process is mostly students lack to mastery physiological anatomical material which seen from the students' scores was still below the criteria of minimal completeness, lack of attitudes and motivation in learning, low capture power and negative perceptions of learning. Whereas external factors is a poor student-teacher relations, less harmonious relationships with parents, and an ideal learning environment. This means the learning objectives of anatomical physiology material have not been well realized and students have difficulty learning.

Refer to the observations that authors get in the field, there are symptoms which indicate that some students have difficulty learning and causing an impact on the low learning outcomes obtained by students on anatomical physiology subjects. Based on this, the author intends to conduct research to find out the issues that cause students have to experience learning difficulties follow with an impact on the low learning outcomes and also the factors of student learning difficulties in anatomical physiology subjects.

\section{THEORETICAL BASIS}

Each student in certainly has the right to obtain opportunities to achieve satisfactory academic performance. But from reality it is clear that students have differences in terms of intellectual abilities, physical abilities, family background, habits and learning approaches that are sometimes very striking between a student and other students. From here, what arises is called as learning difficulty, which does not only affect lowability students, but also experienced by high-class students.

According to Abdurrahman (2003: 6) he said that learning difficulties are a translation of the term English learning disability. Learning difficulties or barriers to learning is a serious problem in the world of education, this is a shared responsibility, especially for teachers, homerooms and educational leaders.

According to Dalyono (2005: 229) explaining learning activities for each individual, not always can take place naturally. In this case sometimes the enthusiasm is high, but sometimes it is also difficult to hold a concentration. Thus, among others, the reality that we often encounter in every student in everyday life in relation with learning activities. Every individual is not the same. This individual difference also causes differences in learning behaviour among students. In a situation where students cannot learn as they should, that is what is called learning difficulties. Learning difficulties are not always caused by low intelligence (mental disorders) but can also be caused by non-intelligence factors, thus, a high IQ does not necessarily guarantee the success of learning, therefore in order to provide appropriate guidance to each student , then educators need to understand the problems and symptoms associated with learning difficulties.

\section{III.FACTORS THAT INFLUENCE LEARNING DIFFICULTY}

According to Dalyono (2005: 230) the someone success or failure in learning is caused by several factors that influence the achievement outcomes, namely factors from the individual students who learn (internal factors) and factors from outside of students who learn (external factors)

Internal factors that exist in students are intellectual ability factors, affective factors such as attitudes and motivation to learn. Whereas external factors include all situations and conditions surrounding the environment that do not support student learning activities such as the attention of teachers and parents.

\section{Internal Factors}

Individual behaviour or activity is not something that happens just like that, but there are factors that encourage by the activities that have that purpose

\section{Attitude}

In everyday life, the existence of attitude has an important role because it will give colour or style to the person's behaviour. Attitude is also a measurement of a person's sensitivity to symptoms and problems arise.

Learning attitude is based on the role of the teacher as a leader in the teaching and learning process. Nevile cited by Djaali (2009: 116) says the teaching style applied by the teacher in the classroom affects the process and student learning outcomes. In this connection, Nasution (1978: 58) 
states that bad relationships with teachers can hinder high learning achievement. The attitude of learning is not only an attitude aimed at the teacher but also to the goals to be achieved, subject matter, assignments and others.

Student learning attitudes will manifest in the form of pleasure or displeasure feeling, agree or disagree, like or dislike of those things. Such an attitude will affect the learning process and results of the achievements. Something that gives rise to pleasure, tends to be repeated. So that it can be concluded that learning attitudes affect one's intensity in learning. When the learning attitude is positive, the learning intensity activities are higher. If the attitude of learning is negative, the opposite will happen. Positive learning attitudes can be equated with interests, interest will facilitate student learning. Because learning will occur optimally in students if he has an interest to learning something. Students who have positive learning attitudes will learn actively.

\section{Motivation}

According to Irwanto, et al (1996: 193) motivation is a theoretical construct regarding to the occurrence of behaviour. This theoretical construct covers aspects of regulation, direction, and purpose of behaviour. It's not easy to get motivation or motivate yourself because someone must be able to regulate attitudes, emotions, behaviours and direct the desired goals so that these goals can be achieved without many obstacles.

The definition above according to researchers can be concluded by what is meant as motivation that has an effort that is realized by the desire to move, direct and maintain one's behaviour so that they are motivated to act and do something with what they are desired as a results. The aim is to determine or limit the behaviour of the individual.

Brophy (2004: 89) states that learning motivation is prioritizes in cognitive response, namely the tendency of students to achieve meaningful and useful academic activities. Students who have motivation to learn will pay attention to the lessons delivered, read material so they can understand it, and use certain learning strategies as a support. In addition, students also have an intense involvement in the learning activities, high curiosity, looking for materials related to understanding a topic, and completing the task given.

Students who have motivation to learn will depend on whether the activity has interesting content or a pleasant process. In essence, motivation to learn involves learning goals and related strategies in achieving these learning goals.

\section{External Factors}

Individual behaviour or activity is not something that just happens, but there are factors that encourage activities that have that purpose.

\section{Teacher's Attention}

Attention is a very important psychological activity, attention has a role in choosing and directing all incoming stimuli through sensing. Thus it is expected that every stimulus, hearing and human attention which is a necessity in supporting mental functions of each individual can make observations. So attention is one of the factors that influence observation, attention is not only accompanied by observation, but also accompanied by other psychological events. And indeed every event that concerns the soul will take place better if it is agreed with good attention.

In the learning process the teacher's attention is a very important factor. According to Ametembun (1990: 2) Teacher is someone who is authorized to be responsible for the education of students both individually and classically, both at school and outside of school. Means in learning process is not limited to the delivery of scientific tasks but also responsible for encouraging, guiding and providing learning facilities for students to achieve the goal as well as to see everything that happens in the classroom to help the student's development process in overcoming difficulties.

As stated by Schell cited Soppah (1995: 9) teacher attention is influenced by teacher appreciation with the future, self, subjects, student appreciation. Schell also added other influences, namely awareness about the progress of education, involvement in student activities, opinions about freedom and orientation of values.

To be guarantee a good learning outcomes, teacher must have attention to students. A teacher must be able to attract the attention of students while teaching and learning activities, because with the attention that students have, further there will be gain a desire which is fixed on a certain thing. According to Sardiman, teacher is a human component in the teaching and learning process, which plays a role in the effort to form potential human resources. The relationship between the teacher and students in the learning process is a very decisive factor. Thus the teacher's attention is the psychological activity given in the learning process and is one of the factors that influence the observation and concentration of all individual student activities whose shown to the objects or groups so as to stimulate students to learn actively and dynamically achieve learning goals.

\section{Parents}

Parents are fathers, mothers of children both through biological or social relationships. Generally, parents have a very important role in raising children. As educators at home, parents play an important role as children's motivators in carrying out activities at school and outside of school.

Dalyono (2005: 238) says family is the main and first education center. But it can also be a factor in the difficulty

\section{IV.DISCUSSION}

Based on processing data from the results of research to 64 students of class X Cosmetology in SMK 3 Tangerang there are factors that influence student learning difficulties 


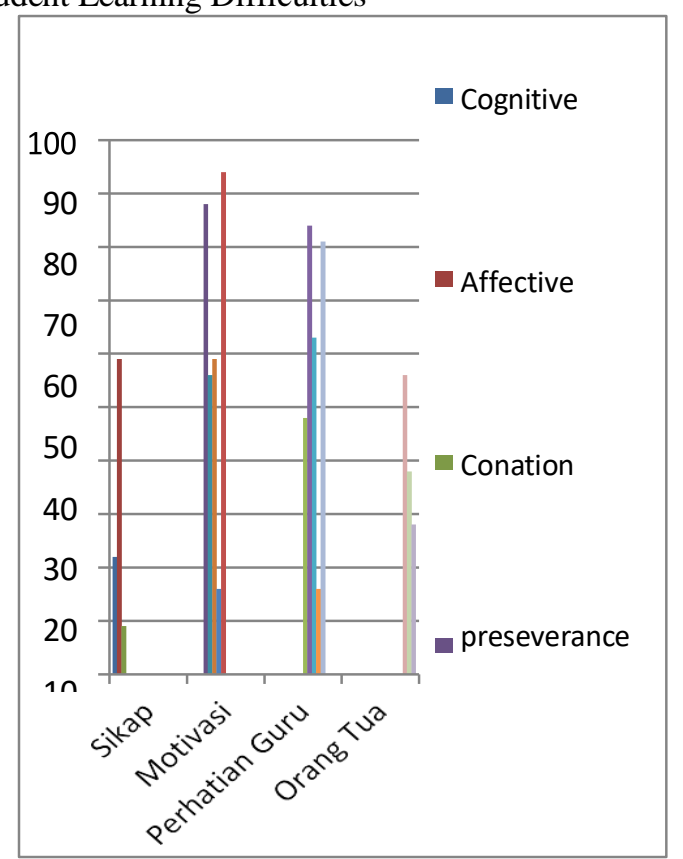

Based on the calculation of the factors percentage value that affect the learning difficulties of student at class $X$ in Cosmetology at SMK Negeri 3 Tangerang, it is found that the factors that affect students' learning difficulties in anatomy physiology subjects are caused by a number of things both from students (internal) and from outside students (external).

Based on the results of the research that has been done, it shows that the factors which do not affect students' learning difficulties are internal factors on attitude indicators with sub-indicators of cognitive, affection, and Conation then motivation indicators with resilient subindicators in facing learning difficulties, interest and sharpness of attention in learning and encouragement for achievement. Whereas on external factors at the indicators of teacher attention with sub-teacher appreciation for students, strengthening teachers towards student appreciation, and awareness about the progress of education. Then indicators of parents with sub-indicators of how parents educate, the atmosphere in the home, and economic conditions.

While the factors that greatly affect learning difficulties in class X students of Cosmetology in the subject of physiological anatomy are internal factors with motivational indicators. On the sub-indicators of perseverance and independence in learning, this is in accordance with the opinion of Sardiman (2010: 75). The intensity of a student's motivation will greatly determine the level of achievement of his learning. In other words, with the diligent effort and especially based on the existence of motivation, then someone who learns will be able to give birth to good achievements and it will reduce or eliminate the level of learning difficulties experienced by students.

Then external factors with teacher attention indicators on sub-indicators of teacher attention to learning difficulties and teacher involvement in student activities, this is in accordance with the theory of Ladjid (2005: 114) that in the components that affect learning outcomes, the teacher component is more decisive because he will manage other components so that it can improve the results of the teaching and learning process. In this case the teacher can be the cause of learning difficulties if the teacher does not fulfill the requirements as an educator, for example: the teacher's relationship is not good with students, the teacher's lack of attention to student learning difficulties.

Based on the results of the research that has been done, it is known that there is a fairly close (moderate), direct and positive relationship between the attention of teachers with learning difficulties of students in physiological anatomy subjects at SMK Negeri 3 Tangerang.

A fairly close relationship is $r$ of 0.247 in this case, intended as evidence that student learning difficulties are influenced by teacher attention. The direction of the relationship between the two variables is positive, meaning that the higher the attention given by the teacher, the higher the student learning outcomes, so that the learning difficulties decrease.

In the regression equation $\mathrm{Y}=101,286+879 \mathrm{X}$, it shows that each increase in the value of a teacher's attention every 101,286 can cause an increase in learning difficulties by 879 by showing an effect of $6.1 \%$ from the coefficient of determination test while the remaining $93.9 \%$ is influenced by other factors. 
Ilmu Pendidikan, Universitas Islam Riau.

By knowing and obtaining this information, it can be interpreted that the high value of the attention of the teacher will affect the increase in student learning difficulties.

If these factors are allowed, then these factors will undoubtedly disrupt the development and abilities of students and will also be fatal, namely the achievement of students who are relatively low or in other words the achievement of the expected learning goals is not achieved. This is a problem that must be solved immediately.

\section{CONCLUSION}

On internal indicators, attitudinal factors with subindicators of cognitive, affection, and conation are classified as less influencing students' learning difficulties in physiological anatomy subjects, namely $59 \%$.

On internal indicators, the motivation factor which has the highest percentage value is the student learning persistence factor which is $88 \%$ and the independent learning factor is $94 \%$. In this case it states that students 'learning persistence factors and student learning independence influence students' learning difficulties on anatomical physiology subjects.

On external indicators, the factor of teacher attention which has the highest percentage value is the factor of teacher appreciation of student learning difficulties which is equal to $84 \%$, and the factor of teacher involvement in student activities is $91 \%$. In this case it states that the factor of teacher appreciation towards students and teacher involvement in student activities affects students' learning difficulties on anatomical physiology subjects.

On external indicators, the factor of parents with subindicators of the way parents educate, the atmosphere in the home and the family's economic condition are classified as less influencing students' learning difficulties in physiological anatomy subjects, which is equal to $56 \%$. In the results of the hypothesis testing the study was obtained through a regression equation where the results of the regression equation obtained were $\mathrm{Y}=101,286+$ $879 \mathrm{X}$, indicating that each increase in the value of a teacher's attention every 101,286 can cause an increase in learning difficulties by 879 with an effect of $6.1 \%$ of the coefficient test determination while the remaining $93.9 \%$ is influenced by other factors.

\section{REFERENCES}

[1] A.M. Sardiman. (2011). Interaksi dan Motivasi Belajar Mengajar. Jakarta: PT Rajagrafindo

[2] Abdurrahman, M. (2003). Pendidikan Bagi Anak Berkesulitan Belajar. Jakarta: Rineka Cipta.

[3] Abdurrahman, M. (2012). Anak Berkesulitan Belajar: Teori, Diagnosis, dan Remediasinya. Jakarta: Rineka Cipta.

[4] Adika, Nur (2010). Faktor-Faktor Penyebab Kesulitan Belajar Mata Pelajaran Ekonomi Pada Siswa Kelas X IPS di SMK Negeri 2 Teluk Kuantan [Skripsi]. Riau: Fakultas Keguruan dan
[5] Ali, M. (2007). Guru dalam proses belajar mengajar. Bandung: Penerbit Angkasa

[6] Anas, Sudijino. (2006). Pengantar Statistik Pendidikan. Jakarta: PT Raya Grafindo Persada.

[7] Arikunto, Suharsimi. (2003). Dasar- Dasar Evaluasi Pendidikan. Jakarta: PT. Bumi Aksara

[8] Azwar, Saifuddin. (2000). Reliabilitas dan Validitas. Yogyakarta: Pustaka Belajar

[9] Basiran (2012). Faktor yang Mempengaruhi Kesulitan dalam Belajar. Jurnal Edukasi, Vol. 7 No. 1, Edisi Maret.

[10] Dalyono, M. (2005). Psikologi Pendidikan. Jakarta: PT Rineka Cipta.

[11] Djaali. (2007). Psikologi Pendikan. Jakarta: Bumi Aksara.

[12] Hadi, Sutrisno. (2000). Metodologi Penelitian. Yogyakarta: Andi Yogyakarta

[13] Hamalik, Oemar. (2006). Psikologi Belajar dan Mengajar. Jakarta: PT Bumi Aksara.

[14] Hamalik, Oemar. (2009). Kurikulum dan Pembelajaran. Jakarta: PT Bumi Aksara

[15] Hamdani, M A. (2011). Strategi Belajar Mengajar. Bandung: Pustaka Setia.

[16] Haryatni, P.A. (2014). Identifikasi Faktor-Faktor Penyebab Kesulitan Belajar Pada Siswa SMP Negeri 5 Kota Jambi [Skripsi]. Jambi: Fakultas Keguruan dan Ilmu Pendidikan, Universitas Jambi.

[17] Jeffrey immanuel H N. (2013). Analisis FaktorFaktor Penyebab Kesulitan Belajar Siswa Terhadap Mata Pelajaran Menggambar Teknik dengan Menggunakan Program Autocad [Skripsi].

[18] Jakarta: Fakultas Teknik, Universitas Negeri Jakarta.

[19] Kadeni. (2006). Peranan Guru dalam Membantu Mengatasi Kesulitan Belajar. Jurnal Cakrawala Pendidikan, Vol 8 No. 1, Edisi April.

[20] Kusanti dkk. (2003). Anatomi dan fisiologi Tata Kecantikan Kulit. Jakarta: Direktorat Pembinan Sekolah Menengah Kejuruan.

[21] Rostamailis, dkk. (2003). Anatomi dan Fisiologi Tata Kecantikan Rambut. Jakarta: Direktorat Pembinan Sekolah Menengah Kejuruan.

[22] Slameto. (2003). Belajar dan Faktor- Faktor yang Mempengaruhinya. Jakarta: PT Rineka Cipta

[23] Syaiful bahri djamarah. (2006). Strategi Belajar Mengajar. Jakarta: Rineka Cipta

[24] UU RI No. 20. 2003. Tentang Sistem Pendidikan Nasional, Bab II Pasal 3. Jakarta: PT Panca Usaha. 